\title{
An Assessment of Market Landscape of Cinnamon in Sri Lanka
}

\author{
I.C. Hettiarachchi", D.A.M. De Silva, M. Esham, T.M. Liyanagamage, A.M.I.P. Abeysinghe, \\ S. Warnakulasooriya and W.A.M. Harindra
}

Date Received: 05 ${ }^{\text {th }}$ April 2019 / Date Accepted: $12^{\text {th }}$ December 2019

\begin{abstract}
Purpose : The cinnamon trade is not only Sri Lanka's oldest trade but the only trade where it holds a monopoly in the world market. Being the leading supplier of true cinnamon to the international market, Sri Lanka is still unable to cater the global demand. Our approach mainly focused to investigate, map and analyze the market landscape of Ceylon cinnamon.

Research Method : Industry insights were drawn from 675 cinnamon growers, 485 peelers, 220 collectors, 50 balers/exporters, 30 value added producers and 50 consumers from Galle, Matara, Kalutara and Ratnapura districts. Stratified and convenience sampling techniques were employed to select appropriate samples. Primary data were collected using internet-based data collection techniques and traditional data collection tools.

Findings : Producer base and peelers were identified as the main upstream actors. Upstream product basket was revealed to comprise with quills (Alba, C5 Special, C5, M1, M2, H1, H2 grades), quillings and featherings. Collectors/dealers, balers, exporters and value-added producers and freight forwarders, off-shore buyers, supermarkets, retailers and consumers collectively represent the downstream. Semiprocessed and ultra-processed products were observed in the basket of value-added product exporters. $38 \%$ of the studied spice traders were emerging participants and they were followed by contenders (24\%), market challenges (16\%), niche participants and market leaders (11\% each). Key brands associated with cinnamon related products available at the main markets; USA, Mexico, Canada, Germany, UK, India and Japan were used to develop the brand landscape.
\end{abstract}

Originality / Value : Discovered stakeholder, institutional and brandlandscapes will drivethe Ceylon cinnamon industry towards success in highly competitive market environments.

Keywords: Cinnamon, Value chain, Brand, Institution, Landscape

\section{INTRODUCTION}

"Peradiga Dhanyagaraya" is the legendary name (implies the meaning 'global grain store of the East) secured by Sri Lanka since the period of ancient kings, holding a reliable competitive position as a world-renowned agricultural country. Further this 'Spice Island' is well-known for its spices export from the time immemorial, growing major spices such as cinnamon, pepper, cardamom, clove and nutmeg which are having an immense export significance. This paper is focused on "cinnamon", which is one of the oldest and the most significant spice grown since many centuries back providing a greater contribution to the Sri Lankan economy.
According to Prof. Lankage (Chairman of the Cinnamon Training Academy of Sri Lanka) "Ceylon cinnamon" was known to mankind since the early days of civilization as the "Miracle Spice of Sri Lanka" and had been a commodity of much value and prestige amongst the nations. Sri Lanka produces and exports about $90 \%$ annually, the best quality true cinnamon while the balance originates from the Seychelles and Madagascar (Ceylon Spice

\footnotetext{
* Department of Agribusiness Management, Faculty of Agricultural Sciences, Sabaragamuwa University of Sri Lanka, P.O. Box 02, Belihuloya

isuru.susl@gmail.com
}

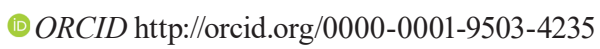


Exporters, 2017). Cinnamon at present, is the fourth most important exporting agricultural crop and the predominant export spice in terms of foreign exchange earnings in Sri Lanka (EDB, 2016). According to Department of Export Agriculture, as of 2009, the total cultivated land extent of cinnamon was 29,415 ha. About 93,767 families with around 150,000 labour units were actively involved in cinnamon cultivation (Bawappa et al., 2005) and it is considered as a part of the lifestyle of the people in Galle and Matara Districts of Southern province. In recent times, extension of this cultivation to several other districts, namely, Hambantota, Ratnapura, Badulla has been noticed. Galle district is the main cinnamon cultivation area with $41 \%$ of share in the total cultivated extent, followed by Matara and Ratnapura districts with $21 \%$ and $14 \%$ of shares respectively. The balance $25 \%$ of the cultivated land extents being shared amongst Hambantota, Badulla, Kalutara, and other districts (DEA, 2014).

Being an indigenous crop to Sri Lanka with less diversified product ranges the cinnamon industry does not show a significant development. Various countries incorporate cinnamon products as a raw material for manufacturing other diversified products while the others use in the same raw form for final consumption. Being an inherited crop that is not possible to grow successfully in any foreign country, the comparative advantage it could provide to Sri Lanka is very high (Thanthirige, 2014). Since the industry is operating at the same traditional level it seems that the value of the entire industry has not been properly understood by most of the stakeholders even in a knowledge-intensive era.

The principal focus of this study was to analyze the Ceylon cinnamon market landscape, which often starts with linear mapping of activities in the cinnamon value chain from the initial input suppliers at the very beginning of the production process to the final consumption of products. Specific objectives focus on two main areas, the first on market mapping; production system mapping, stakeholder mapping, brand mapping and influencer mapping and the second on identifying strategies to upgrade the Sri Lankan cinnamon industry. This paper contributes to the literature on agricultural value chains by assessing the industry/stakeholder capabilities and identifying the opportunities to prioritize towards the development of the Ceylon cinnamon industry.

\section{MATERIALS AND METHODS}

The study was carried out in Galle, Matara, Kalutara and Ratnapura districts in Sri Lanka based on mixed method approach because of its advantages in exploring social realities associated with cinnamon value chain. 675 cinnamon growers, 485 peelers, 220 collectors, 50 balers/exporters, 30 value added producers and 50 consumers were considered for the study in order to draw realistic industry insights. Both stratified and convenience sampling techniques were used to locate respondents. In the sampling process, randomization applied in two steps; during the selection of GN divisions and in the selection of households within selected GN divisions. Business profiles of 124 spice traders who have been involved in cinnamon trading and registered at the Export Development Board were considered when developing the "Competitive Market Landscape". Internetbased data collection techniques (such as study stakeholder websites, subscribe to stakeholder mailing lists, follow stakeholders on social media, set-up Google alerts, use online surveys, purchase competitive products, discussions with sales force/distribution partners, field and factory visits, attend trade shows/exhibitions and foreign visits etc.) along with traditional data collection tools (interviewer administered questionnaires, focused group discussions, indepth interviews with key industry stakeholders etc.) were used to collect primary industry intelligence which were required to develop stakeholder, influencer and brand maps. Central Bank Annual Reports, reports published by the Department of Census and Statistics, Industry Capability Reports published by the Export Development Board and progress reports published by the Department of Export Agriculture were used as secondary data sources. The keying and analysis of the quantitative data were enhanced by using Minitab 16.0 
Statistical Software Package. Strategies were then developed to achieve greater benefits from Ceylon cinnamon industry considering the unmet needs and untouched potentials. Figure 01 explains the conceptual framework of the study.

\section{RESULTS AND DISCUSSION}

\section{Cinnamon value chain in Sri Lanka}

Data collected from various sources were grouped into three categories; functions, actors and products, to develop the Ceylon cinnamon value systematically. Input supply, production, collecting and trading, exporting and value addition and consumption were identified as the main functions of the studied value chain. Different types of actors performing different functions were then identified along with different products at each stage.

As illustrated by Figure 02, upstream of the Ceylon cinnamon value chain comprises the producer base (fulltime growers; small, medium or large scale, part time growers, plantation companies, producer societies, broad tree processing factories etc.) and cinnamon peelers involved in the primary activities. According to the findings, majority of the producers (about $70 \%$ ) were small holders and do not cultivate Cinnamon as fulltime engagement. This is in line with the findings of UNIDO (2016); most of the cinnamon growers are part-timers, engaged in other professions as their main livelihood. The producer associations were identified as the main horizontal linkage in this part of the value chain. Ceylon Cinnamon Association (CCA), also known as "Lanka Kurundu Sangamaya" is the pioneer amongst these. Cinnamon Cultivators Association (CinCA) is the other main producer association. Cinnamon peelers were identified to have an established network called "Kalli" most of these groups were revealed to comprise with family members, relatives, or own community members who mainly coordinate on their payment demands. Quills (mainly belongs to Alba, C5 Special, C5, M1, M2, H1,H2 grades), quillings and featherings were identified as the main upstream products. This is not totally in line with the upstream products identified by UNIDO (2016). According to them around $30 \%$ of cinnamon should be of Alba quality, $60 \%$ of grades $\mathrm{C} 4 / \mathrm{C} 5$ and the remaining $10 \%$ of grade $\mathrm{H} 2$. The main support activities at this part of the value chain were: (a) input suppliers like fertilizer and other agro-chemical dealers, plant nurseries, and other farm equipment and machinery suppliers; and (b) extension services which are provided by DEA; field demonstrations, training, advisory and fertilizer and plant subsidies. It was further revealed that the large scale producers have started to obtain services of the private sector companies for fertilizer demand analysis and recommendations.

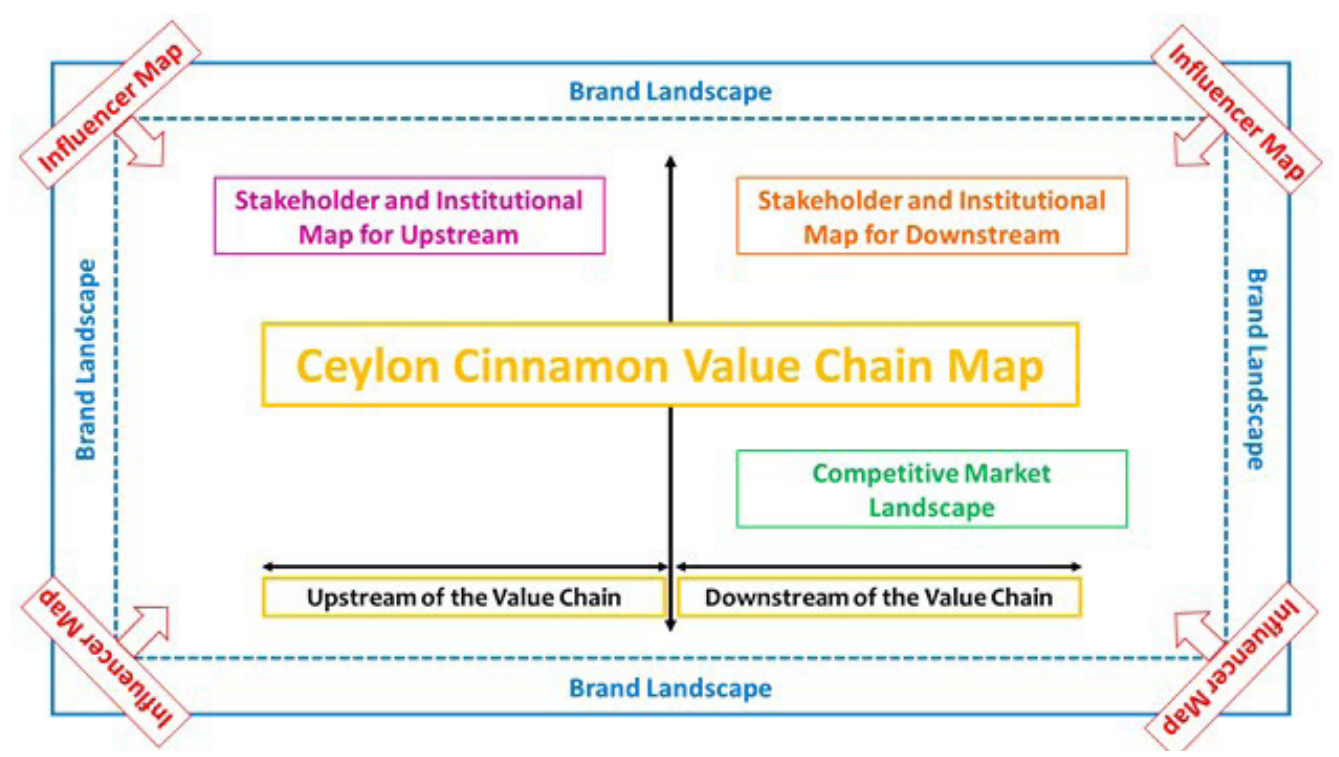

Figure 01: Conceptual Framework 


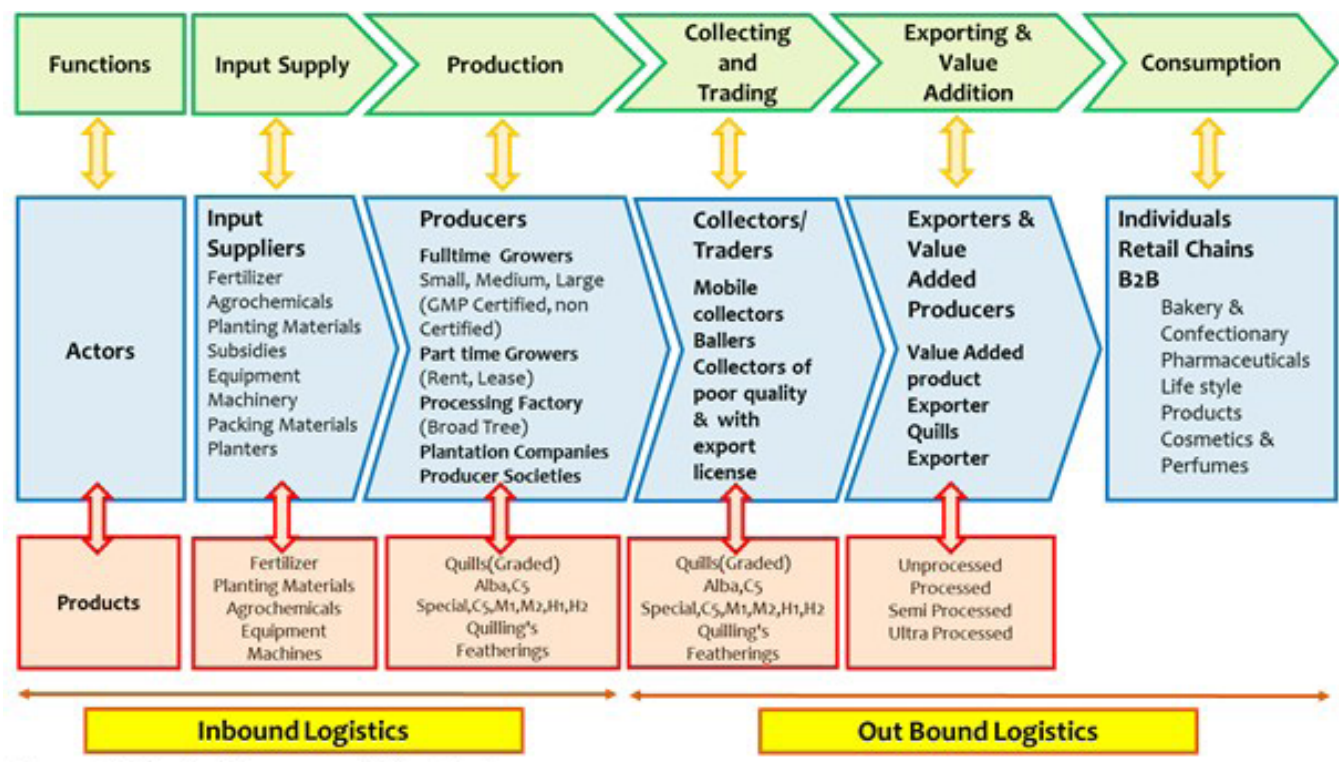

Figure 02: Ceylon Cinnamon Value Chain

Downstream of the value chain were revealed to comprise with the collectors (or commonly called traders), ballers, exporters and value-added producers, freight forwarders, off-shore buyers, supermarkets and retailers, and the consumers. Collectors/dealers, balers, exporters and value-added producers and freight forwarders collectively represent the local segment of the downstream while, off-shore buyers, supermarkets and retailers and the consumers collectively represent the international segment of the downstream. The collectors were revealed to engage in the collection and distribution of raw material supplies (cinnamon quills) across the chain and the balers attend to the sorting, grading, and fumigating (with sulphate) of the cinnamon supplies. The exporters act as the final link in the domestic market structure and they can be categorized into two categories; quills exporters and valueadded product exporters. Both semi-processed and ultra-processed products were observed in the basket of value-added product exporters. According to UNIDO (2016), in Sri Lanka, few companies have embarked on cinnamon based products such as Cinnamon oils, soaps, hand wash, incense sticks, candles, lifestyle items, cinnamon tea etc. for direct consumer markets. Almost all quills exporters were revealed to sell through brokers or commission agents located in the importing country, who resell the quills to manufacturers of bakery \& confectionary items, pharmaceuticals, life style products, cosmetics $\&$ perfumes etc.

\section{Stakeholder and institutional map of the Ceylon cinnamon value chain}

Though the value chain analysis often starts with linear mapping of activities in the chain from the initial input suppliers at the very beginning of the production process to the final consumption of products or services, it is apparent that the performance of any value chain is always influenced by various supporting functions and rules and regulations. This study investigated each of the supporting functions (e.g. information, training, inputs, subsidies, finance, logistics and legal/regulatory etc.) shaping the functioning of the Ceylon cinnamon value chain separately for both the up-stream and the down-stream.

As illustrated by Figure 03, supportive services extended by various government/nongovernment institutions and other stakeholders to ensure the effective functioning of the upstream of the cinnamon value chain were grouped into three categories; advisory/extension, input/ subsidies and financial services. Agriculture Research Institute, Cinnamon Research Institute, Cinnamon Training Academy, Ceylon Cinnamon Association and other farmerbased associations were identified as the major institutes that extend advisory/extension services. Ministry of Primary Industries, banks (both public and private), financial institutes and money lenders were identified as financial service providers. Department of Agriculture, 
Department of Export Agriculture, Department of Agrarian Services along with few leading private sector companies were recognized as important upstream stakeholders since they provide multiple services (advisory/extension and input/subsidies) extending support for the effective functioning of the upstream of the Cinnamon value chain.

Performance of the downstream of cinnamon value chain was identified to be influenced by various supportive services providers and legal/regulatory bodies (Figure 04). National Engineering Research and Development Centre, Agricultural Insurance Board, The Spice Council, Udaya Industries (Pvt) Ltd. were identified as the leading material and machinery related supportive service providers to the down-stream actors. Majority of the identified logistic providers and freight forwarders were private sector institutions. Sri Lanka Standards Institution, Sri Lanka Accreditation Board, Plant Quarantine Service, Ministry of Health, Consumer Affairs Authority, Ministry of Primary Industries, Export Development Board, Department of Inland Revenue, Industrial Technology Institute and SGS Lanka (Pvt) Ltd. were identified as Sri Lanka's leading inspection, verification, testing and certification institutions who offer a complete range of services for manufacturers, agents, traders, exporters, importers and consumers helping their business to become more sustainable by improving quality and productivity, reducing risk and verifying compliance. It was further identified that National Chamber of Exports, Export Development Board and Department of Export Agriculture play a duel role as a supportive service provider and regulatory body while Sri Lanka Customs and Sri Lanka Ports Authority perform all the three functions; supportive, logistic and regulatory, shaping the effective functioning of the downstream of the cinnamon value chain.

\section{Influencer map of the Ceylon cinnamon value chain}

Information obtained from focused group discussions and in-depth interviews with key industry stakeholders were used to recognize the government institutions/ authorities, legal/regulatory bodies at local level and intergovernmental organizations and international non-profit organizations that can make an impact on Cinnamon value chain, acting as "influencers"in its own "interconnected" market system (Figure 05). According to Nutz and Merten (2015), this type of diagnostic process is vital to understand often-complex market systems and to arrive at the real underlying constraints (in interconnected markets) that can be intervened into a maximize scalable and sustainable change in the core value chain.

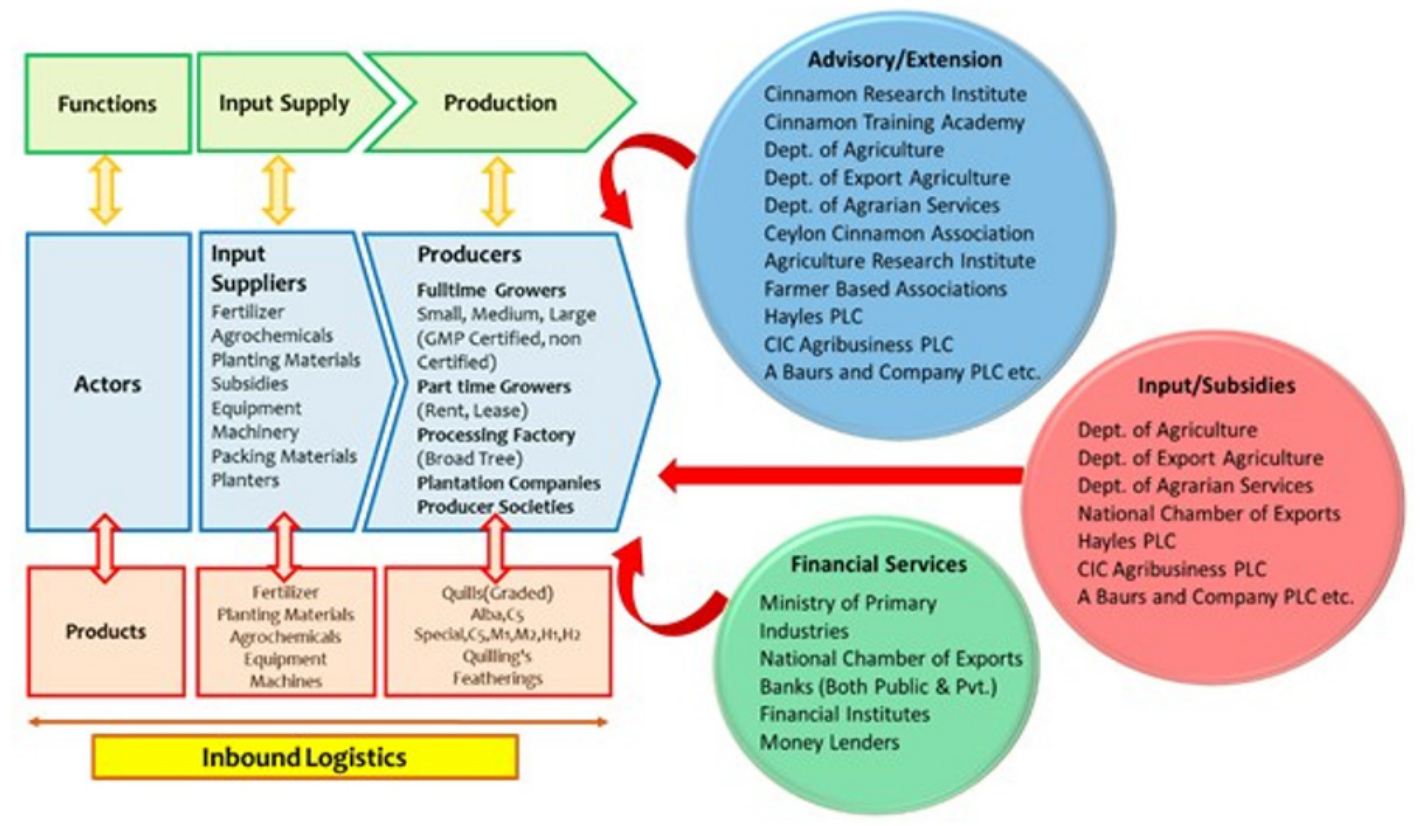

Figure 03: Stakeholder Map of the Up-stream 


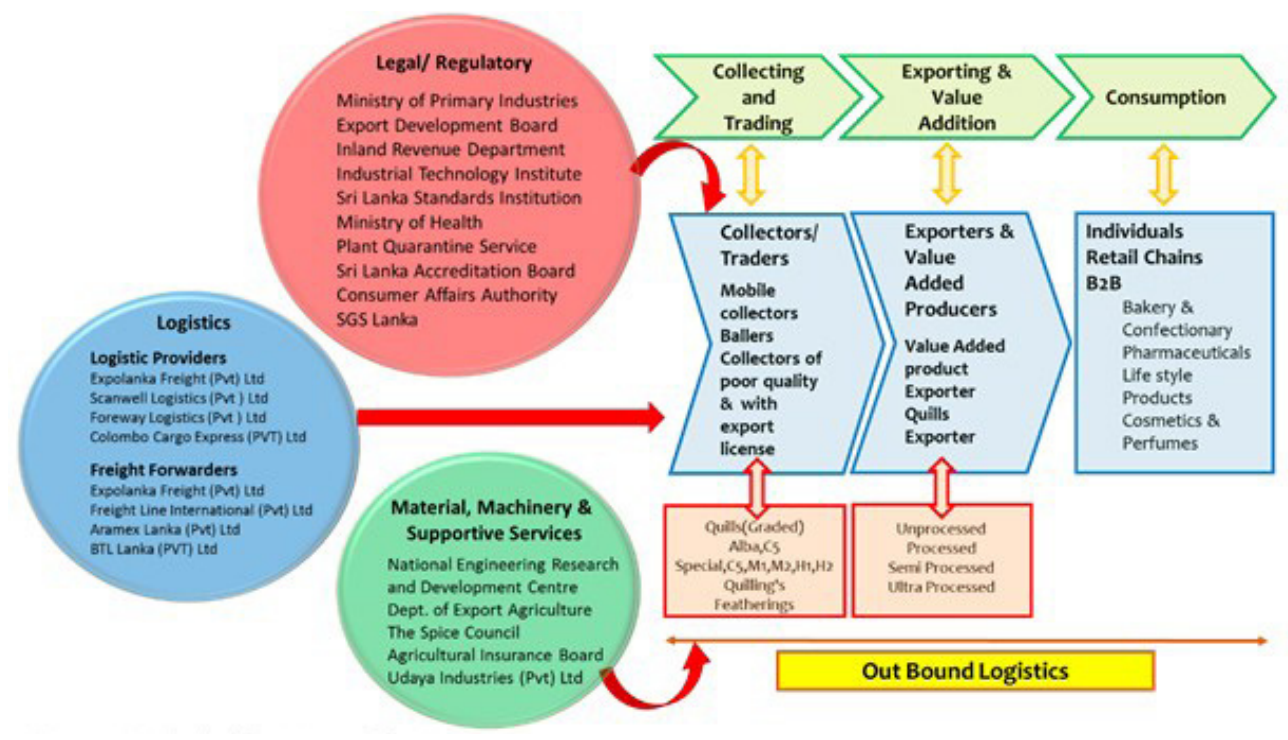

Figure 04: Stakeholder Map of the Down-stream
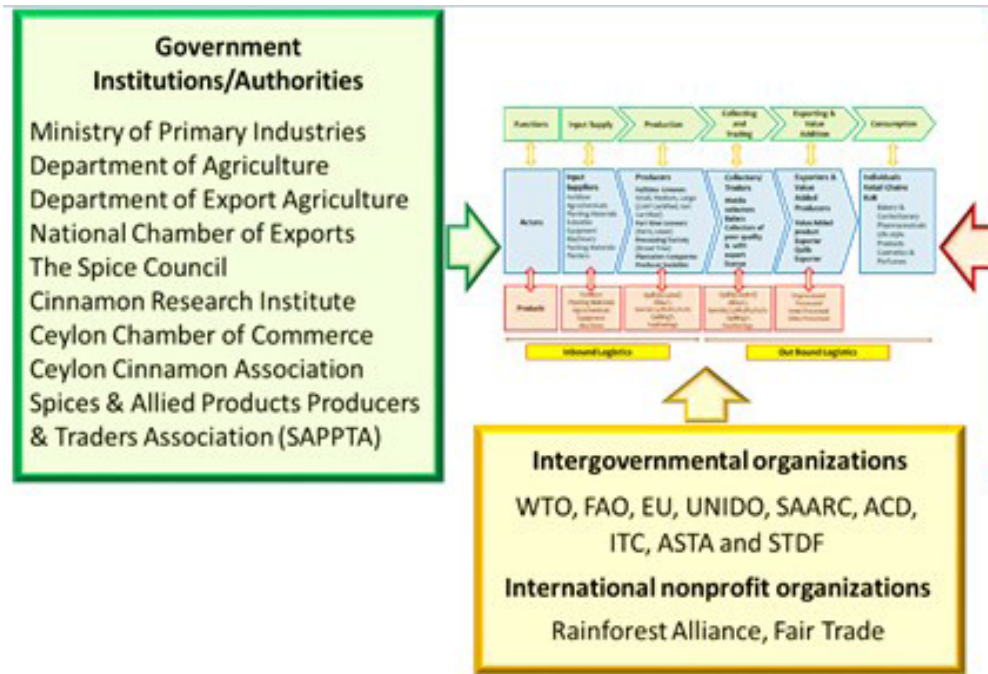

Legal/Regulatory Bodies

Industrial Technology Institute Sri Lanka Standards Institution Sri Lanka Accreditation board Export Development Board Inland Revenue Department Ministry of Health Plant Quarantine Service Sri Lanka Customs Consumer Affairs Authority Organic Certification Bodies Ex: Control Union, IMO etc.

\section{Figure 05: Influencer Map of Ceylon Cinnamon Value Chain}

In addition to the government institutions/ authorities and legal/regulatory bodies identified as "influencers" at local level, The World Trade Organization (WTO), The Food and Agriculture Organization of the United Nations (FAO), The European Union (EU), The United Nations Industrial Development Organization(UNIDO), The South Asian Association for Regional Cooperation (SAARC), Asia Cooperation Dialogue (ACD), International Trade Center (ITC), American Seed Trade Association (ASTA), and The Standards and Trade Development Facility (STDF) were identified as the inter-governmental organizations which were negotiated and signed by the bulk of the world's trading nations and ratified in their parliaments enabling them to deal with the rules of trade between nations, ensuring that the trade flows as smoothly, predictably and freely as possible. Further, Rainforest Alliance and FairTrade movement were identified as international nonprofit organizations; whose stated goals are to help producers in developing countries to achieve better trading conditions and to promote sustainable farming, and categorized as "global influencers" along with inter-governmental organizations considering their power to make an impact on cinnamon value chain.

\section{Competitive market landscape analysis}

Business profiles of 124 spice traders were then grouped into five pre-developed categories; niche participants, contenders, emerging participants, market challengers and market leaders, based on their trade performance to 
develop the "Competitive Market Landscape". Table 01 below illustrates the definitions and respective percentages of the spice traders belong to each category.

\section{Brand landscape for Ceylon cinnamon}

Having the monopoly of supplying "True cinnamon" to the world market, Sri Lanka annually earn over 17 billion rupees (120 million dollars) in foreign currency (EDB, 2016), exporting cinnamon to over seventy (70) countries, spreading across almost all continents. USA, Mexico, Canada, Germany, United Kingdom, India and Japan were identified as the main buyers of Ceylon cinnamon. Internetbased data collection techniques were employed to identify the key brands associated with the cinnamon and cinnamon related products available at the identified markets. Table 02 illustrates the "Brand Landscape" of Ceylon cinnamon.

Table 01: Competitive market landscape of the Sri Lankan cinnamon industry

\begin{tabular}{clc}
\hline Category & \multicolumn{1}{c}{ Definition Given } & Percentage \\
\hline Niche Participants & $\begin{array}{l}\text { Participants who aim to satisfy the needs of a specific market, in } \\
\text { view of the product quality, price range and the demographics that } \\
\text { is intended to impact }\end{array}$ & $11 \%$ \\
\hline Contenders & $\begin{array}{l}\text { Participants who are traditional processors, with no/less product } \\
\text { diversification and different from a competitor who takes on every } \\
\text { unexpected challenge }\end{array}$ & $24 \%$ \\
\hline \multirow{2}{*}{ Emerging Participants } & $\begin{array}{l}\text { Participants who display blend of characteristics of 'niche } \\
\text { participants' and 'market leaders', but do not meet the standards } \\
\text { to become a 'niche participant' or a 'market leader' }\end{array}$ & $38 \%$ \\
\hline Market Challengers & $\begin{array}{l}\text { Participants who make attemptsto expand the market share by } \\
\text { aggressively flooding the market with products at competitive } \\
\text { prices under their brand name/s. }\end{array}$ & $16 \%$ \\
\hline Market Leaders & $\begin{array}{l}\text { Participants with the largest market share in the industry, and who } \\
\text { can use its dominance to affect the competitive landscape and } \\
\text { market direction }\end{array}$ & $11 \%$ \\
\hline
\end{tabular}

Table 02: $\quad$ Brand landscape of Ceylon cinnamon

\begin{tabular}{|c|c|}
\hline Market & Brands \\
\hline USA & $\begin{array}{l}\text { FRONTIER, INDUS ORGANICS, BUY WELLNESS, MARSHALLS CREEK SPICE, } \\
\text { OREGON'S Wild Harvest, McCormick }\end{array}$ \\
\hline Mexico & $\begin{array}{l}\text { FRONTIER, INDUS ORGANICS, BURMA SPICE, BADIA, POWERNUTRISHOP, } \\
\text { DRUERA, CINNAMON VOGUE, HERB, ORGANIC WISE, KIVA Health, ZHOU } \\
\text { Nutrition, TERRASOUL Super Foods, Naturevibe Botanicals, Coconut Country } \\
\text { Living's, Sunny Day Organics, Supper Food Harvest, Simply Organic, BLUE LILY } \\
\text { Organics, Organic Masala, Healthworks, Green Pack, McCormic, Diyesta, Nutriflair, } \\
\text { hayllo, spicely organics }\end{array}$ \\
\hline Canada & $\begin{array}{l}\text { FRONTIER, ORGANIC WISE, NUTRABOTANICA, MASCOT, GABAN, DRUERA, } \\
\text { BURMA SPICE, CINO CEYLON, KURUDU, BLUE LILY Organics, Laksoil, Wild } \\
\text { Tusker, Trade Thecnocart, Splender Garden, herb affairs }\end{array}$ \\
\hline Germany & NATURTEIL, EDEL KRAUT, FRONTIER, Real Herbs, Puressetial, azafran, wohltuer \\
\hline $\begin{array}{l}\text { United } \\
\text { Kingdom }\end{array}$ & $\begin{array}{l}\text { SEVENHILLS, DRUERA, ORGANIC WISE, FRONTIER, YOGI ORGANICS, } \\
\text { PRANAROM, LIFETONE G, Stay Fresh Organics, Hatton Hill Organic, Cinnamora, } \\
\text { Authentic Oil Co., Live Organics, Lucy Bee, Just Ingredients, Lebensbaum, Sena- } \\
\text { Herbal, Joannas Garden, Ben Condito, Dolfin, Penzeys, Biotiva, Arkopharma }\end{array}$ \\
\hline India & $\begin{array}{l}\text { HOME OF SPICES, CEYLON CINNAMON SHOP, MYSTIQUE HILLS, KEYA, } \\
\text { Natural Choice BOTANICALS, NutriONN, Herbs India, Brown Tree, Drifruitmart, } \\
\text { healthbuddy }\end{array}$ \\
\hline Japan & GABAN, MASCOT, McCormick \\
\hline
\end{tabular}




\section{Untouched potentials of value addition in Ceylon cinnamon}

Since the current market position is not sufficient to harness to the fullest potential of the Sri Lankan cinnamon industry, brainstorming sessions were conducted with industry stakeholders to reveal some of the additional potentials associated with cinnamon and they can be mentioned as follows; guided tours (visits to cinnamon factories, estates and cinnamon small holders can be included into touristic programs), peeling knife (similar to the "Swiss Knife", the small, handy versions of the peeling knife can be developed and sold to tourists as souvenirs, spice gift packs (gift packs containing a variety of spices packaged in attractive packages can be developed and sold as souvenirs), crafts (walking sticks, furniture or picture frames can be made out from peeled Cinnamon sticks), Cinnamon paper (cinnamon wood paper can be used for gift cards, letters, serviettes, corporate gifts or notebooks), filling materials (remaining scrapples could be utilized to fill pillows, mattresses and similar items which would emit a benevolent smell of cinnamon), cleaner production (peeled cinnamon sticks as biomass, to generate electricity or hot water). Though some of these value additions are already produced, they are at very small scale. Therefore, this could be the high time for relevant authorities/stakeholders to drive towards these untouched potentials to thrive in highly competitive market environments.

\section{CONCLUSIONS}

Fulltime growers; small, medium or large scale, part time growers, plantation companies, producer societies, processing factories, cinnamon peelers who collectively represent the local segment of the upstream, collectors/dealers, balers, exporters/value-added producers and freight forwarders who collectively represent the local segment of the downstream and offshore buyers, supermarkets and retailers and the consumers who collectively represent the international segment of the downstream make the Sri Lankan cinnamon value chain highly complex. Though the Sri Lankan government extends various supports (e.g. information, training, inputs, subsidies, finance, logistics and legal/regulatory etc.) in cooperation with various private and non-governmental organizations, members of the value chain; especially members of the upstream, do not seem to harness the fullest benefits of those. Research inputs should be shared with both upstream and downstream members of the value chain and value addition should be encouraged along the value chain. Cash grants and loan schemes should be introduced to encourage emerging participants to expand their business to the next level. An effective promotional campaign should be designed and implemented in a planned way specially to gain high market share over cassia in the main markets. At the same time, a proper mechanism should be established to identifying important international gateways and to explore new market segments opening up new gateways for all the stakeholders to achieve wider benefits.

\section{ACKNOWLEDGMENT}

The authors are thankful to National Science Foundation and Ministry of Primary Industries for financial assistance (SP/CIN/2016/05) and Sabaragamuwa University of Sri Lanka for administrative assistance.

\section{REFERENCES}

Agriculture and Food Council. (2004). Value Chain Initiative: Value chain guidebook - a process for value chain development, Agriculture and Food Council of Alberta, Nisku (Canada). Available from www.agfoodcouncil.com. Sited $23^{\text {rd }}$ October 2016.

Altenburg, T. (2007). Donor approaches to supporting pro-poor value chains: Report prepared for donor committee for enterprise development, working group on Linkages and value chains, S.I. Donor committee for Enterprise Development, ILO, Geneva 
Bawappa, K.V.A., Rutmann, R.A., Gunaratne, W.D.L. and Abeykoon, A.M.D. (2005). Technical Bulletin No 5: Cinnamon Plantation and Preparation. Colombo: Department of Exnort Agriculture. Sri Lanka.

Bolwing, S. (2010). Integrating poverty and environmental concerns into value chain analysis: A conceptual framework, Development Policy Review, 28(2), pp173-194

Central Bank of Sri Lanka. (2014). Annual report, Central Bank of Sri Lanka.

Department of Export Agriculture. (2014). Annual report, Department of Export Agriculture

Department of Export Agriculture. (2011). Annual report, Department of Export Agriculture

Department of Export Agriculture. (2009). Annual report, Department of Export Agriculture

Herath, Anura, and Weerasinghe, J. (2004). Cinnamon. Department of Export Agriculture, Sri Lanka.

Herath, P.H.M.U. (2003). Factors determining intercropping by rubber smallholders in Sri Lanka. Agricultural Economics, 29, pp159-168

Gereffi, G. (1994) 'The Organisation of Buyer-driven Global Commodity Chains: How U.S. RetailersShape Overseas Production Networks', in G. Gereffi and M. Korzeniewicz (eds), Commodity Chains andGlobal Capitalism, Westport, CT: Praeger: 95-122

Kaplinsky A. (2004). Spreading the gains from globalization: what can be learnt from value-chain analysis, Problems of economic transition, Vol. 47, No. 2: 74-115

Madey, D. L. (1982). Some benefits of integrating qualitative and quantitative methods inprogram evaluation, with illustrations. Educational Evaluation and Policy Analysis, 4(2),223-236.

NutzNadja and SieversMerten (2015). A rough guide to value chain development: a short guide for development practitioners, government and private sector initiatives, International Labour Office- Geneva.

Porter, Michael E. (1985). Competitive Advantage: Creating and Sustaining Superior Performance. New York. Simon and Schuster. Retrieved 9 September 2013

Spice Exporting Industry of Sri Lanka. (2017, November 17). Retrieved from Ceylon Spice Exporters: http://www.srilankabusiness.com/spices/

Sri Lanka Exports Development Board (2016). Annual Report and Statement of Accounts, Sri Lanka Exports Development Board.

StammAnreas and Drachenfels Christian (2011). ILO value chain development approaches and activities by seven UN agencies and opportunities for interagency cooperation, Geneva

Thanthirige, J. B. (2011). Technological and marketing issues in Cinnamon industry in Sri Lanka. Sri Lanka: University of Moratuwa.

UNIDO (2016). Enhancing the compliance and productive capacities and competitiveness of the cinnamon value chain in Sri Lanka, United Nations International Development Organization, Geneva. 